\title{
AZ ÉGHAJLATVÁLTOZÁS HATÁSÁRA FELLÉPŐ KÖRNYEZETI VÁLTOZÁSOK ÉS TERMÉSZETI VESZÉLYEK
}

\author{
DUNKEL ZOLTÁN-BOZÓ LÁSZLÓ-GERESDI ISTVÁN \\ ENVIRONMENTAL CHANGES AND NATURAL HAZARDS \\ CAUSED BY CLIMATE CHANGE
}

\begin{abstract}
This article provides an inventory based on Intergovernmental Panel on Climate Change (IPCC) reports that suggest that changes in the Earth's system, and primarily atmospheric changes, can be attributed to global warming. The majority of the changes are connected with the phase change of the Earth's water, changes in glaciers, and the decrease of ice cover. A further indication of this global change can be seen in the change of the annual course of precipitation in many places. In some regions droughts occur more frequently, while in other regions more intense precipitation has been recorded. The effects of global warming in agriculture and forestry are detected in the higher latitudes. The vegetation period starts earlier and the growing season has become longer and longer. Besides the evident rise in temperature that has been detected in meteorological data, significant changes were demonstrated in the observed marine and freshwater biological systems. The detected changes could be consequences of rising water temperature and of decreasing ice cover, of changes of salinity modification, and of change in oxygen content and circulation. After summarising the general signals of climate change, the impact of the warming that has started and that very probably will continue is assessed using the results of climate models and impact studies based on these models. We deal with climate change influences in the hydrosphere separately. Finally, we summarise the possible weather changes in Hungary and in its closest neighbors in the Carpathian Basin. The regional climate models show significant increases in temperature in every season. In the case of precipitation the future is more complicated. The only clear prognosis is that significant decreases could be forecasted in summer. The warming from 1980 to the present in accordance with the global tendency is not only evident in Hungary, but also more severe. The rate of warming is higher in Hungary than the global mean. The average increase for the period 2021-2050 in Hungary is expected to be $1-2^{\circ} \mathrm{C}$, for $2071-21003-4^{\circ} \mathrm{C}$. The average rainfall is expected to decline. However, with respect to the number of rainy days exceeding $20 \mathrm{~mm}$ of precipitation, the rainfall intensity shows a slight increase.
\end{abstract}

Keywords: influences of climate change, global warming, climate model results, hydrosphere, expected weather of Carpathian Basin

\section{Bevezetés}

Az éghajlatváltozás, a globális felmelegedés tényét ma már kevesen vitatják. A folyamat hátterében nagy valószínúséggel az emberiség áll, elsősorban az ún. üvegház-gázok mértéktelen, s a különböző nemzetközi egyezmények és fogadkozások ellenére nem csökkenő kibocsátásával. Ez a megállapítás viszonylag újszerű, mivel az éghajlatváltozással foglalkozó legnagyobb nemzetközi szervezet, az Éghajlat-változási Kormányközi Testület, az IPCC csak a harmadik jelentésében foglalt úgy állást, hogy a melegedés oka az antropogén hatás. A Föld növekvő energia-bevétele, a megemelkedett sugárzási kényszer elsődleges következménye a melegedés. Az elfogadott konszenzus szerint ha ennek mértéke felszíni globális átlagban meghaladja a $2^{\circ} \mathrm{C}$-os emelkedést az ipari forradalom előtti átlaghoz képest, akkor a Földön olyan visszafordíthatatlan folyamatok fognak végbemenni, ami jelenlegi civilizációnk fenntarthatóságát alapjaiban kérdőjelezi meg (IPCC 
2007; IPCC 2011). Az éghajlati rendszerben azonban már most is szép számmal láthatók olyan változások, illetve fordulnak elő olyan, elsôsorban időjárási események, amelyek már most aggodalomra adnak okot.

\section{Az éghajlatváltozás általános jelei a földi rendszerekben}

A hó és a jég előfordulásaiban - az örökké fagyott talajt is beleértve - bekövetkezett változásokra tekintettel nagy a bizonyossága annak, hogy a természetes rendszerekre az éghajlatváltozás már hatással van. Ilyen a gleccsertavak kiterjedésének és számának növekedése, a felszín instabilitásának növekedése az örökké fagyott talajú területeken. Sok helyen a gleccserek vagy teljesen eltűntek, vagy jelentôs mértékben visszahúzódtak, a sziklaomlások gyakoribbá váltak a hegyvidéki területeken, továbbá változások történtek egyes északi- és déli-sarki ökológiai rendszerekben, a tenger jeges életközösségeiben, valamint a táplálkozási lánc csúcsán lévő ragadozók körében.

Az egyre növekvő számú bizonyítékok alapján határozottan kijelenthetô, hogy a vízrajzi rendszerekben számolni kell megváltozott lefolyással, gleccser- és hóolvadékvízzel táplált folyók esetében korábbi tavaszi csúcsvízhozammal, valamint sok területen a tavak és folyók melegedésével, ami egyúttal hatással van a vízminőségre is.

A különböző megfigyelésekből származó adatok, bizonyítékok alapján elmondható (IPCC 2007), hogy a jelenlegi felmelegedés jelentősen hatást gyakorol egyes fajok élőhelyére, a szárazföldi és a tengeri biológiai rendszerekre. Ezek legnyilvánvalóbb, s egyértelmú jelei az olyan változások, mint például a kitavaszodás jelentős eltolódása, a korábbi rügyfakadás, virágba borulás, a madarak vándorlásának és tojásrakásának korábbi bekövetkezése, s ami leginkább kimutatható, a növény- és állatfajok jelentős sokaságának a magasabb szélességek, a sarkok felé történő elvándorlása. A globális felmelegedés hatására a mezőgazdaságban és az erdőgazdálkodásban a magasabb északi szélességeken korábban indulhat meg a vegetáció, ami a mezőgazdasági termelésben korábbi tavaszi kiültetést, illetve korábbi kihajtást eredményezhet. Ugyanakkor, mivel a globális felmelegedés nem jelent egyenletes változást, egyes helyeken a tavaszi fagyok gyakoribb megjelenését lehet megfigyelni. A korai felmelegedéssel együtt járhat a gyorsabban csökkenő víztartalom, a kiszáradási hajlam, ami sok esetben az erdôtüzek kialakulását, a kórokozok elszaporodását segíti elő az erdei rendszerekben.

Ez a jelenség olyan kis területen is kimutatható, mint Magyarország, ahol a múlt század ötvenes éveiben még csak a déli határ mentén megfigyelt kártevők a század végére már a Budai-hegységben is megjelentek.

A korai kitavaszodás jól megfigyelhető az 1980-as évek végétől végzett múholdas megfigyelések alapján. A felvételeken jól kimutatható, hogy sok területen a növényzet korábbi tavaszi „,kizöldülése” felé történt eltolódás, a melegedés miatt hosszabb tenyészidőszak alakult ki.

Jelentős változás figyelhető meg a tengeri és az édesvízi biológiai rendszerekben. A megfigyelt változások az emelkedő vízhőmérsékletekkel, valamint az ezzel összefüggésben a jégborítás csökkenésével, a sótartalom módosulásával, az oxigénszintekben és a keringésben bekövetkezett változásokkal állnak kapcsolatban. Ezek legfeltűnőbb jelei az algák, a plankton és a halak számának nagyságrendi eltolódásai az óceánok magasabb földrajzi szélességeken levő zónái felé. Hasonlóan megnövekedett ezek száma a tengerszint felett magasan fekvő tavakban és megváltoztak a folyami halak elterjedési területei, korábbi vándorlási irányai is.

A szén-dioxid koncentrációjának antropogén növekedése az ipari forradalom kezdete óta az óceánok savasabbá válását eredményezte. Az óceánok pH-értéke átlagosan 0,1-del 
csökkent. Mindazonáltal az óceán savasodásának a tengeri bioszférára gyakorolt közvetlen hatása még nem bizonyítható.

A különböző vizsgálatok és tanulmányok átfogó szintézise azt mutatja, kizárt, hogy a Föld egyes területein megfigyelt jelentős melegedés, illetve több rendszerben megfigyelt, a globális felmelegedéssel összefüggésbe hozható, jelentős változások térbeli egyezése kizárólag a hőmérsékletek vagy a rendszerek természetes változékonysága miatt következett volna be.

Azt azonban meg kell említeni, hogy a mért és a megfigyelt reakciók okait teljesebb mértékben nem lehet kizárólag az emberi tevékenység okozta globális felmelegedésnek tulajdonítani, mivel a rendelkezésre álló nagyszámú bizonyíték ellenére a megfigyelt területek száma korlátozott és véges. Ugyanakkor a természetes hőmérséklet-változékonyság regionálisan sokkal nagyobb, mint globálisan. Ez a tény a külső hatások miatt bekövetkezett változások azonosítását jelentősen befolyásolja. Regionálisan más tényezők is hatással lehetnek, ilyenek a földhasznosítás, a levegő- és vízszennyezés, valamint bizonyos fajok elterjedésének változásai.

Az igen nagyszámú mérésből és megfigyelésből származó bizonyítékok mellett meg kell említeni, hogy számos különböző típusú modell is arra az eredményre jutott, hogy a légköri és a biológiai rendszerekben bekövetkező változásokat az emberi tevékenység által okozott felmelegedéssel lehet leginkább megmagyarázni. A rendszerekben megfigyelt változásokat összehasonlították a különböző modellezett reakciókkal, ahol a természeti (napsugárzás, vulkánkitörések hatásai) és az emberi tevékenységből származó hatásokat kifejezetten elkülönítették egymástól. A kombinált természeti és emberi tevékenységbool származó kényszerhatásokkal rendelkező modellek a megfigyelt reakciókat sokkal jobban szimulálják, mint a csak természeti kényszerhatásokkal rendelkezők.

A különböző tanulmányokban összefoglalt számos mérés és megfigyelés, a különböző szintű és bonyolultságú modelleredmények teljes mértékben azonos következtetésre jutottak. Ez a közös következtetés - mint az a különböző IPCC jelentésekben olvasható a jelentős regionális felmelegedés és a globális szintú hatások közötti térbeli egyezőség nagy bizonyossággal az emberi tevékenységekből származó felmelegedésnek tulajdonítható. A természetes és emberi környezetre gyakorolt regionális klímaváltozásnak más hatásai is jelentkeznek, habár ezek közül többet nehéz egyértelmúen kimutatni az esetleges alkalmazkodás és a nem klimatikus hatások miatt.

A globális felmelegedés az élővilágban nemcsak a növényzetre és az állatvilágra van hatással, hanem az emberi egészséget is befolyásolja. A megnövekedett átlaghőmérséklet a gyakorlatban nagyobb nappali maximumokat és kisebb mértékú éjszakai lehúléseket eredményez, hosszabb hőségperiódusokkal. Ezek az időszakok néhány esetben nagyszámú, a hőséggel közvetlenül összefüggő halálozással járnak és járhatnak Európában is. Bizonyos fertőzőbetegség-hordozók megjelenése egyes területeken, valamint az allergiát okozó növények elterjedése, a pollenkoncentráció megváltozása a közepes és magasabb északi szélességeken szintén a hőmérséklet-emelkedés rovására írható.

A globális felmelegedésnek nemcsak negatív hatásai vannak, hanem számolhatunk pozitív következményekkel is. Bizonyos emberi tevékenységek folytathatókká válnak a melegedés hatására az Északi-sarkkörön túl is (pl. vadászat vagy utazás havas vagy jeges területeken). Ugyanez elmondható hegyi sportok esetében egyes alacsonyabb alpesi területeken is. A magasabb hegyvidéki területeken ugyanakkor a települések fokozott veszélynek lesznek kitéve az olvadó gleccserek által okozott vízmozgások, a gleccsertavak esetleges áradásai miatt.

Míg a közepes és magasabb szélességeken elsősorban hosszabb tenyészidőszakkal lehet számolni, addig a Száhel-övben a melegebb és szárazabb időjárás, a kevesebb csa- 
padék a tenyészidőszak rövidülését okozza. A rövidebb tenyészidőszak a rosszabb vízellátással együtt a terméshozamot mind mennyiségileg, mind minőségileg kedvezőtlenül érinti. Dél-Afrikában a hosszabb száraz időszakok és a bizonytalan csapadékjárás a víztartalékok drámai csökkenéséhez, a víztározók kiürüléséhez vezethet, ami már nemcsak a mezőgazdasági terméshozamot veszélyezteti, hanem egyes nagyvárosok vízellátása is veszélybe kerülhet. A globális felmelegedés sokat emlegetett következménye a tengerszintemelkedés. Ez a jelenéség múholdas mérésekkel jól kimutatható. Sem a bekövetkezett, sem a modellek által a század közepéig előre jelzett $1,0-1,9^{\circ} \mathrm{C}$ hőmérséklet-emelkedés (BARTHOLY J. et al. 2011) nem túnik veszélyes mértékűnek, de a további melegedés és az ezzel járó tengerszint-emelkedés a közvetlen tengerparti településeken, egyes alacsony szigeteken komolyan veszélyeztetheti az ott élők élet- és vagyonbiztonságát, fôként a váratlan tengerparti áradások, a szökőárok okozta hatások miatt.

\section{A klímamodellekből és a hatástanulmányokból levonható következtetések a várható változásokról}

Az évszázad közepéig várható, hogy az évi átlagos felszíni lefolyás és a hasznosítható vízkészlet a magasabb szélességeken és néhány nedves trópusi területen 10-40\%-kal növekszik (IPCC 2007; 2011). Ugyanakkor 10-30\%-os csökkenés várható egyes, közepes földrajzi szélességen fekvő helyeken és a száraz trópusi, ma is vízhiánnyal sújtott száraz területeken. Egyes helyeken és bizonyos évszakokban a változások ettől az éves jellegtől eltérnek. A szárazság által sújtott területek kiterjedése valószínúleg növekszik. Az intenzív nagycsapadékok gyakorisága nagy valószínúséggel nőni fog, ami fokozza az árvízi kockázatot.

Az évszázad folyamán a gleccserekben és a hóval fedett területeken tárolt vízkészlet az előrejelzések szerint csökkenni fog, ami csökkenti a hasznosítható vízkészletet a nagy hegységrendszerek olvadékvizéből táplált területeken, ahol jelenleg a világ lakosságának több mint egyhatoda él.

A globális felmelegedés és a hozzá kapcsolódó, a korábbiaktól jelentósen eltérő körülmények számos ökológiai rendszer alkalmazkodási képességét valószínúleg meg fogják haladni. E „más állapotok” - a megszokottól eltérő viszonyok - között kiemelt jelentőségúek az árvizek, a száraz időszakok, a tartós aszályok, a szárazság miatt gyakrabban kialakuló tüzek, rovarinváziók, valamint az óceán vizének savasodása. A káros következményeket mindenképp erősíthetik egyéb, nem közvetlenül a globális melegedést kiváltó emberi tevékenységek is. Ilyen a földhasználat változása, a környezetszennyezés, az eróforrások túlságosan nagymértékú kiaknázása. Ezek együttesen komoly környezeti, éghajlatváltozásból eredő károkhoz vezethetnek.

A 21. században a szárazföldi ökológiai rendszerek nettó szénfelvételének maximális értékét nagy valószínúséggel a század ötvenes évei előtt fogja elérni. Ezt követôen a szénfelvétel gyengülni fog, ami a további melegedés irányába hat.

Ha a globális átlaghőmérséklet-növekedés meghaladja az 1,5-2,5 C-ot, akkor az eddig érintett növény- és állatfajok 20-30\%-a valószínúleg fokozott kihalási veszélynek lesz kitéve.

A növekvő légköri szén-dioxid-mennyiség hatására az óceánok kémhatása jobban eltolódik a savas értékek felé, ami nagy valószínúséggel negatív hatással lesz a mészhéjas szervezetekre, a korallokra és a tőlük függő fajokra. A korallok nemcsak a savasodásra reagálnak, hanem a hőhatással szemben is sérülékenyek, mivel alkalmazkodóképességük gyenge. A tengervíz $1-3^{\circ} \mathrm{C}$-os felszíni hőmérséklet-növekedése valószínúleg gyakoribb korallfehéredési eseményeket és nagy területre kiterjedő pusztulást okozhat, hacsak a korallok nem fognak alkalmazkodni vagy hozzászokni a hőmérsékletváltozás okozta hatásokhoz. 
A globális léghőmérséklet emelkedésével együtt járó felszíni és felszínközeli vízhőmérséklet-emelkedés következményeként egyes halfajok mozgásában és szaporodásában szembetűnő regionális változások várhatók. Ez a folyamat a vízi kultúrákra és a haltenyészetekre nézve hátrányos következményekkel jár majd. A partvidékek további éghajlatváltozási kockázata a tengerszint-emelkedésből származó partvidék-erózió. A hatást az egyre nagyobb mértékú emberi tevékenység is súlyosbítani fogja. A tengerszint emelkedése a partvidéki nedves területeket, sós mocsarakat és mangrovékat is valószínúleg negatívan fogja befolyásolni.

A közepes és magas szélességeken, ahol a lokális hőmérséklet nem emelkedik jobban 1- $3^{\circ} \mathrm{C}$-nál, a mezőgazdasági termelés - terménytől függően - várhatóan kissé növekedni, az ennél jobban melegedőknél csökkenni fog. Alacsonyabb szélességeken, különösen az időszakosan száraz és trópusi területeken a mezőgazdasági termelés mennyisége még a csekély helyi hőmérséklet-növekedések hatására is várhatóan csökkenni fog, ami egyes területeken a jelentős élelmiszerhiányt, éhínség kialakulását teszi nagymértékben valószínúvé. Ugyanakkor az egész Földet illetően várhatóan növekedni fog az élelemtermelési potenciál, elsősorban az $1-3^{\circ} \mathrm{C}$ közötti lokális átlaghőmérséklet-növekedésú területeken, e fölött viszont csökkenés várható.

A várhatóan szélsőséges csapadékjárás eredményeként az aszályok és áradások gyakorisága megnövekszik, s ez minden bizonnyal csökkenti a helyi mezőgazdasági termelést, különösen az alacsony szélességi körökön található megélhetési szektorokban. Az alkalmazkodások, például a módosított kultúrnövény-változatok és ültetési idők révén az alacsony, közepes és magas szélességi körökön levő gabonatermések a mértékadó terméshozamokon vagy azok fölött tarthatók kisebb felmelegedés esetén is. Globálisan a kereskedelmi faanyag-terméshozam mérsékelten nő a rövid és középtávú éghajlatváltozással, de nagy regionális változékonyságot mutat majd a globális trend körül.

A 21. század utolsó évtizedeiben majd minden évben sok millióval több ember fog szenvedni az árvíztől a tengerszint-emelkedés miatt (IPCC 2013). Azok a súrűn lakott és alacsonyan fekvő területek, ahol az alkalmazkodóképesség viszonylag alacsony, és amelyeknek már most is más kihívásokkal - trópusi vihar, hurrikán, a partvidék süllyedése is szembe kell nézniük, különösen veszélyeztetettek (afrikai és ázsiai óriásdelták, az óceánok nagyon alacsony, kis szigetei).

Az éghajlatváltozás következményei nemcsak a természetes környezetben, a hidroszférában és a bioszférában mutatkoznak meg, hanem az ember élettelen, épített környezetében, a különböző lakó- és iparterületeken is. Ezek a hatások az esetek többségében a rendszer fenntartási költségeit illetően többletkiadásokkal járnak. Az ipar, a települések és a társadalom számára az éghajlatváltozás többletköltségei és az esetleges előnyökből származó bevételei hely és nagyságrend szerint igen eltérők lesznek. A vizsgálatok és a modell-szimulációk azt mutatják, hogy összességében a hatások végeredménye annál negatívabb lesz, minél jelentősebb az éghajlatváltozás, azaz minél erősebb a globális felmelegedés. A legsebezhetőbb iparágak, települések és társadalmak általában azok, amelyek a partvidékeken és folyók árterületein találhatók, továbbá azok, amelyek gazdasága szorosan összekapcsolódik az éghajlatra érzékeny erőforrásokkal és szélsőséges időjárási eseményekre hajlamos területeken találhatók, különösen ott, ahol gyors városiasodás zajlik.

A szegény közösségek különösen sebezhetők lehetnek, különös tekintettel azokra, amelyek a nagy kockázatú területeken összpontosulnak. Valószínúleg korlátozottabb az alkalmazkodóképességük, és jobban függnek az olyan, éghajlatra érzékeny erőforrásoktól, mint például a helyi víz- és élelmiszerellátás. Ahol a szélsőséges időjárási események intenzívebben vagy gyakrabban fordulnak elő, az események közgazdasági és társadalmi 
költségei nőni fognak. A növekedések várhatóan a legközvetlenebbül érintett területeken lesznek a legjelentősebbek. A közvetlenül érintett területekről az éghajlati változás hatásai kiterjedt és bonyolult kapcsolatokon keresztül átterjednek más területekre is. A várható éghajlatváltozással kapcsolatos érintettségek valószínúleg emberek millióinak egészségi állapotát is jelentősen befolyásolni fogják, különösen a rossz alkalmazkodóképességúekét. Ezek közül ki kell emelni az alultápláltságot és az abból következő rendellenességeket, különös tekintettel a gyermekek növekedésére és fejlődésére gyakorolt hatásokat.

A hőhullámok hatására megnövekszik a halálozási, megbetegedési és sérülési arány, az árvizek, a szökőárok, a hurrikánok és tájfunok előfordulási gyakorisága, a szárazföldön a viharok, tornádók, valamint a tűzesetek száma. Az éghajlatváltozással összefüggő magasabb talajszinti ózonkoncentrációk miatt növekszik egyes hasmenéses betegségek száma, valamint a keringési-légzőrendszeri megbetegedések gyakorisága. Néhány fertőző betegség hordozóinak térbeli eloszlása is megváltozik. Az áradásokkal és az aszályokkal összefüggő hasmenéses megbetegedési és halálozási arányok várhatóan emelkedni fognak Kelet-, Dél- és Délkelet-Ázsiában, a hidrológiai ciklusnak a globális felmelegedéssel kapcsolatos várható változásai miatt. A parti vizek hőmérsékletének emelkedése valószínúleg súlyosbítani fogja a kolera elterjedését Ázsia déli részén.

Az éghajlatváltozásnak várhatóan vegyes hatásai is lesznek. Ilyen az afrikai malária mértékének és terjedési potenciáljának csökkenése vagy fokozódása. A mérsékelt övi területeken, fóként iparosodott országokban végzett tanulmányok kimutatták, hogy az éghajlatváltozás valószínúleg bizonyos előnyökkel is jár majd, például kevesebb haláleset lesz a hideg idő következtében. Általánosságban várható, hogy ezeket az előnyöket a világszerte emelkedő hőmérséklet negatív hatásai különösen a fejlődő országokban ellensúlyozni fogják.

Az európai területeket hátrányosan érintheti a jövőbeli éghajlatváltozás némely hatása, s várhatóan fokozza a regionális különbségeket Európa természetes eróforrásaiban és javaiban. A negatív hatások magukban foglalják a hirtelen árhullámok megnövekedett kockázatát, a tengerpartok gyakoribb elöntéseit és fokozott erózióját a szélviharok és a tengerszint emelkedése miatt. Az élő szervezetek és ökoszisztémák nagy többsége nehezen fog alkalmazkodni a klímaváltozáshoz. A hegyvidéki területeknek a gleccserek visszahúzódásával, a hótakaró csökkenésével egyre kisebb téli idegenforgalommal és a fajok nagymértékű kihalásával kell szembenéznie. Dél-Európában a hőmérséklet-emelkedés és az aszály várhatóan rontja olyan területek adottságait, amelyek már most is sérülékenyek, ahol a hasznosítható vízkészlet és a vízenergia-potenciál csökkenő tendenciát mutat, csökkenhet a gazdasági jelentőségú nyári idegenforgalom és általában a mezőgazdasági terméshozam. A hőhullámok növekvő egészségügyi kockázatán kívül az erdőtüzek gyakoriságának növekedésével is számolni kell. Az erdők termőképessége valószínúleg romlik, és növekszik a tőzeges mocsarakban a tûzesetek gyakorisága. Közép- és Kelet-Európában várható a nyári csapadékmennyiség csökkenése, ami növekvő vízgondokat és különösen a nyári időszakban a folyók esetében alacsony vízállásokat eredményezhet (1. kép).

Észak-Európában a klímaváltozás kezdetben valószínúleg vegyes hatásokat vált ki, néhány előnyt is beleértve, mint például a csökkenő fütési igényt, a növekvő terméshozamokat és a fokozott erdőnövekedést. Az éghajlatváltozás negatív hatásai, a gyakoribb téli árvizek valószínúleg felülmúlják a változás előnyeit, veszélyeztetik az ökoszisztémákat, ide számítva a növekvő talaj-instabilitást is.

A természetben élő, valamint a tenyésztett állatok klímaváltozási érintettsége még nem került a kutatások érdeklődési körébe, miközben a rendkívüli hőmérsékleti helyzetek, extrém csapadékviszonyok akár a növénytermesztés érintettsége miatt közvetve, akár közvetlenül is komoly hatást gyakorolhatnak az állatok élettevékenységére. 


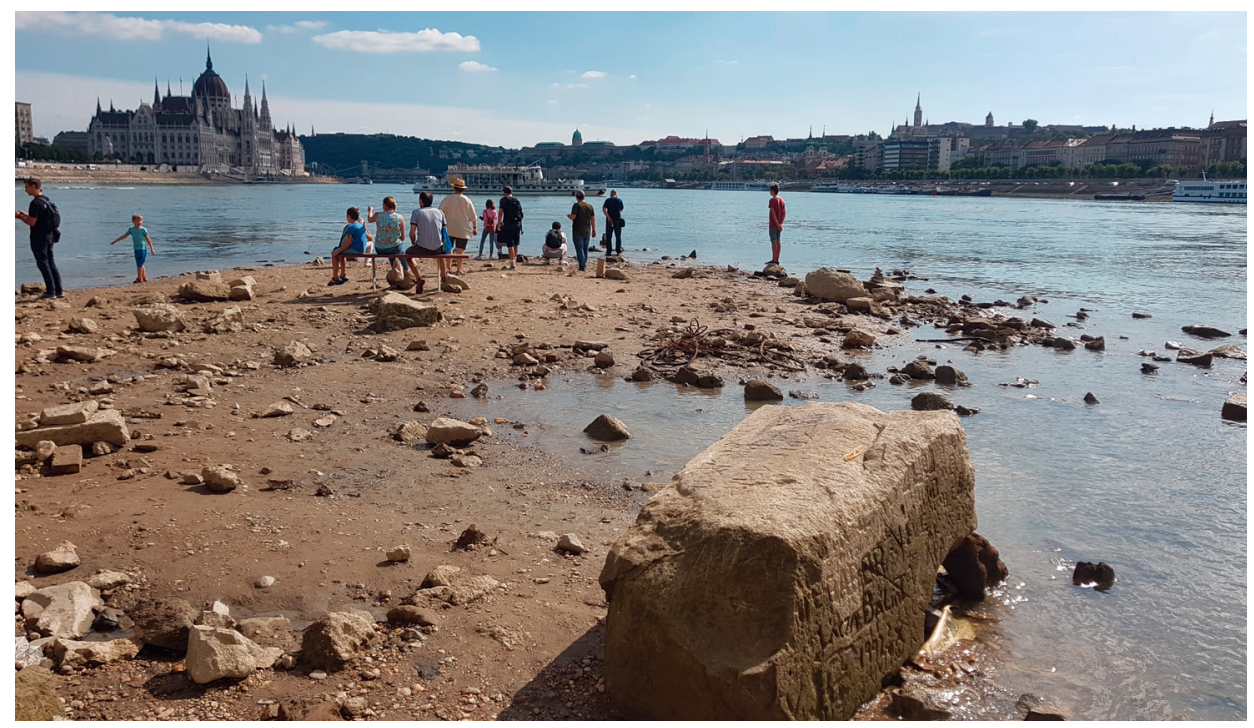

1. kép Alacsony vízállás a Dunán 2018 nyarán

Figure 1 Low water level at the Danube in the summer of 2018

Forrás/Source: Jenki Sz. felvétele/Photo by Jenki, Sz.

A klímaváltozás folytán gyakoribbá váló extrém időjárási események a különböző területeken élő, eltérő helyzetú csoportokat nem azonos módon érintik. Annak mértékét, hogy egy társadalmi csoport várhatóan mekkora kárt vagy mennyire súlyos negatív hatásokat szenved el a klímaváltozás hatására, a társadalmi sérülékenység fogalma fejezi ki. A sérülékenység három tényező eredője: az időjárási változásoknak és az extrém eseményeknek való kitettség, az e hatásokkal szembeni érzékenység, valamint az e hatásokkal való megbirkózás képessége, azaz az alkalmazkodóképesség. Ezek a szempontok nemcsak a humán elszenvedőkre igazak, hanem a különböző állati egyedekre és populációkra is.

\section{Az éghajlatváltozás hatásai a földi hidroszférára}

A földi vízkörforgalomban meghatározó a légkör szerepe. A párolgás, a kondenzáció, a felhő- és csapadékképződés, valamint a légmozgások révén a légkör játssza a legfontosabb szerepet a víz folyamatos körforgásában a természetes víztározók között. Ez a rendszer a globális felmelegedés hatására azonban megváltozik. A globális cirkuláció folyamatában fontos szerepet kap a víz. A nyugati szelek övében kialakuló ciklonok erősségét alapvetően befolyásolja, hogy bennük mennyi vízgőzz képes kicsapódni és ezzel együtt mennyi látens hő szabadulhat fel. A ciklonokban történő nedvességkicsapódás felhő- és csapadékképződéssel jár. A nagyobb csapadékot adó ciklonok jellemzően gyorsabban fejlődnek (GERESDI I. et al. 2013). A kontinenseket sújtó aszályok, illetve az árvizeket okozó esőzések kialakulásának feltételeit legtöbbször nem a helyi légköri állapothatározók, hanem a globális földi cirkuláció körülményei szabályozzák.

A természetes és antropogén okokra visszavezethető globális környezeti változások jelentős részben a víz globális körforgalmának változékonyságához köthetők. A globális változásokkal is kapcsolatba hozható regionális és lokális léptékű természeti jelenségek bizonyos helyzetekben súlyos élet- és vagyonvédelmi kockázatot jelentenek. Az 1980-2015 
közötti időszakra vonatkozó adatok szerint a bekövetkezett természeti káresemények száma a 2000-es évek 500 feletti maximuma után enyhe csökkenéssel az utóbbi öt évben 350 körül látszik stabilizálódni (EM-DAT 2016). Láthatjuk, hogy az árvizek, az aszályok és a gyakran intenzív csapadékeseményekkel is kísért légköri viharok együttesen ennek jelentős részéért felelősek.

A különböző természeti katasztrófák által sújtott személyek száma ugyanerre az időszakra 50 és 650 millió között változik: a kiugró 2002-es évet nem számítva, az utolsó évtizedben 150 millió körül ingadozik. A természeti katasztrófák - földrengés, árvíz, vihar, aszály, járvány - közül a leginkább károkozó esemény a vízzel van összefüggésben. A tartós és jelentős vízhiány, valamint a szélsőséges csapadékesemények nyomán kialakuló áradások összességükben domináns szerepet játszanak. A vízkészletek stratégiai szerepe világszerte felértékelődött. Az integrált vízgazdálkodás egyrészt a társadalmi elvárásoknak megfeleló gyakorlati feladat, másfelől megvalósulása a víz természeti és társadalmi körforgásának egységes, tudományos megalapozottságú és rendszerszemléletű figyelembevételét teszi szükségessé. Fontos a hidrológiai és a meteorológiai közszolgáltatások összehangolt szemléletű kezelése.

A globális felmelegedés, a klímaváltozás egyik, számos vizsgálat által igazolt következménye a szélsőséges időjárási események számának és intenzitásának megnövekedése. Ezeknek majd mindegyike közvetlenül kapcsolódik a víz földi körforgásához. A hidrometeorológiai megfigyelőrendszerek, valamint az előrejelzési szolgáltatások folyamatos fejlesztése és bővítése elengedhetetlenül szükséges annak érdekében, hogy a csapadék területi és időbeni eloszlásának, intenzitásának változásait egyre pontosabban és megbízhatóbban nyomon követhessük, ami elősegíti a kármérséklési és alkalmazkodási feladatok végrehajtását is az árvízi és belvízi védekezés során, a hirtelen lehulló, nagy mennyiségú csapadék nyomán kialakuló villámárvizek (flash flood) következményeinek kezelésében, valamint az aszály okozta várható károk mérséklésében.

\section{Várható időjárás-változások a Kárpát-medencében}

A klíma előrejelzést illetően, az IPCC AR4-nek megfelelően, két jövőbeli időszakra, 2021-2050-re és 2071-2100-ra készültek előrejelzések. A változásokat pedig minden esetben az 1961-1990 időszak átlagaihoz viszonyítva adják meg. Meg kell említeni, hogy az IPCC AR5 ettől a rendszertől eltér. A meteorológiai gyakorlatban elfogadott és használt, a klímastandard alapjának tekintett 30 éves időszakról áttért 20 éves időszakokra. A hagyományos és megszokott éghajlati feldolgozások (PÉCZELY GY. 1979; 1984) alapján kialakított éghajlati képet lassan egy másik, módosult éghajlatra kell kicserélni. A Kárpátmedence időjárását alapvetően a nagytérségi folyamatok határozzák meg. A mérsékelt övi ciklonok mind gyakoribb északabbra húzódásával térségünket sokszor az időjárási frontoknak csak a déli ága érinti. A globális felmelegedés hatása 1980 óta hazánkban is megfigyelhetô. Az évszakos változásokat tekintve a tavaszok (százados trend $1,1^{\circ} \mathrm{C}$ ) és a nyarak (százados trend $1,2^{\circ} \mathrm{C}$ ) intenzívebben melegedtek. Ósszel $\left(0,7^{\circ} \mathrm{C}\right)$ és télen $\left(0,6^{\circ} \mathrm{C}\right)$ a hőmérséklet növekedése kisebb mértékú volt (BARTHOLY J. et al. 2011). Elmondható, hogy országos átlagban a melegedés üteme nagyobb, mint a globális melegedés. 2021-2050-re a magyarországi éves átlaghőmérséklet várható növekedése $1-2^{\circ} \mathrm{C}, 2071-2100$-ra pedig 3-4 ${ }^{\circ} \mathrm{C}$ az 1961-1990 közötti referencia-időszakhoz viszonyítva. Mind a napi maximum-, mind a napi minimumhőmérséklet legnagyobb mértékben várhatóan nyáron fog növekedni.

A Magyarországon mért évi csapadékmennyiség jelentős részét a frontátvonulások, illetve a fölöttünk hullámzó légköri frontok adják. A hidegfrontok térségünket éppen 
csak elérő déli ága legtöbbször csak a szél északi irányúra fordulását és viharossá fokozódását eredményezi, rendszerint kevés csapadék kíséretében (HoRvÁTH Á.-NAGY A. 2012). A Földközi-tenger medencéje fölött kialakuló mediterrán ciklonok gyakorisága csökkenő tendenciát mutat. A mediterrán ciklonok csapadéksávja gyakran okoz jelentős mennyiségű csapadékot hazánkban. Elmaradásuk ugyancsak hozzájárul az aszályos időszakok kialakulásához. Amikor viszont ősszel a sivatagi hatás visszahúzódik, a nyáron felmelegedett Földközi-tenger jelentős mennyiségben adja át a nedvességet a húvösebb légkörnek, és a déli részeken igen erôs csapadékot adó, heves ciklonok jöhetnek létre. A jelenséget - hurrikánhoz hasonlítva és a mediterrán jelzővel társítva - újabban „,medicane” névvel jelölik (HoRvÁTH Á.-NAGY A. 2012). A medicane-t a hurrikánok esetében is megfigyelhető lassú mozgás, a trópusi jellegú mag és a jól szervezett zivatarfelhőzet jellemzi. Mozgási energiáját és víztartalmát a meleg Földközi-tengerből nyeri. A rendszerben jelentős nyomásváltozás mérhető, kiadós esőzéseket, igen erős szeleket és széllökéseket okoz. Gyakorisága és pusztító hatása nem éri el a hurrikánokét, hiszen kialakulásának és fennmaradásának geográfiai feltételei, valamint a tengervíz mélysége és termodinamikai jellemzői különbözőek.

Országos átlagban csökken a csapadékos napok száma, a 20 mm-es összeget meghaladó csapadékos napok viszont enyhe növekedést mutatnak. A száraz időszakok, vagyis az a leghosszabb időszak, amikor a napi csapadékösszeg nem éri el az $1 \mathrm{~mm}$-t, a megfigyelések szerint a 20. század eleje óta megnövekedett. A napi intenzitás, más néven az átlagos napi csapadékosság - egy adott periódusban lehullott csapadékösszeg és a csapadékos napok számának hányadosa - a nyári évszakban ugyancsak nőtt. Az átlagos napi csapadékok növekedése arra utal, hogy a csapadék egyre inkább rövid ideig tartó, intenzív záporok, zivatarok formájában hullik (LAKATOS M. et al. 2016).

A jövőre valószínúsíthető állapotokat a különböző klímamodellek eredményei foglalják össze. Az IPCC jelentésekben (IPCC 2007b; 2007c; 2007d) bemutatott eredmények, illetve a globális modellek leskálázásával a hazai modellek foglalkoznak (SzÉPSZÓ, G. 2008; SzÉPSZÓ, G.-HoRÁNYI. A. 2008). A globális eredményekkel (IPCC 2011) összhangban a magyar regionális klímamodellek (BARTHOLY J. et al. 2011) szerint 21. században folytatódik az átlaghőmérséklet emelkedése a Kárpát-medencében, mégpedig minden évszakban szignifikáns módon. A növekedés abban a tekintetben is folyamatos, hogy a vizsgált 2071-2100 közötti időszakban ez nagyobb mértékú (átlagosan 3,5C), mint 2021-2050 között (amikor az átlagos melegedés $1,7^{\circ} \mathrm{C}$ ).

A legnagyobb változások a nyári időszakra várhatók a 2021-2050 időszakban: a modell szerint 1,4-2,6, míg az évszázad utolsó évtizedeire ugyanezen nyári időszakra 4,1-4,9 C melegedés várható. A hőmérséklet-emelkedés területi eloszlását tekintve a projekciók egységesek abban, hogy az ország keleti és déli területein kell nagyobb mértékú melegedéssel számolnunk.

A csapadék esetében a kép már kevésbé egyértelmú, mert a modellek eredményei csak néhány esetben bizonyultak statisztikailag szignifikánsnak. A 2021-2050 időszakra vonatkozóan az éves csapadékösszeg változatlanságában és a nyári csapadékátlag 5-10\%-ot elérő csökkenésében jobbára egységesek. Ugyanakkor vannak azonban olyan területek is, főként hazánk északi tájai, ahol a modelleredmények kismértékú nyári csapadéknövekedés lehetôségére is felhívják a figyelmet. Tavasszal és télen a két modell (RegCM, illetve ALADIN-Climate, REMO; SzÉPSZÓ, G. - HorÁNYI, A. 2008; BARTHOLY J. et al. 2011) teljesen eltérő jövőképet ad. A 10\%-ot meg nem haladó mértékű növekedés, illetve a hasonló arányú csökkenés mindkét évszakban egyaránt lehetséges. Az évszázad közepén tapasztalt évszakos változások tovább folytatódnak, de nem minden esetben erôsödő jelleggel. Nyáron 20\%-ot meghaladó csökkenés várható az ország egész területén. Ốsszel országos 
átlagban a növekedés lesz jellemző, de az egyes tájak esetében itt is vannak eltérések a projekciók között. Az évszázad végére az éves csapadékátlag csökkenése elérheti az 5\%-ot.

\section{Összefoglalás}

A különböző IPCC jelentések alapján leltárba vettük a globális felmelegedésnek tulajdonítható változásokat a földi rendszerekben, elsősorban a légkörben. Az éghajlatváltozás általános jeleinek összefoglalása után a megindult és valószínúleg tovább folytatódó melegedés várható hatásait összegeztük a klímamodellekből és az azokon alapuló hatástanulmányokból levonható következtetések alapján. Külön kitértünk a klímaváltozás hatásaira a földi hidroszférában. Befejezésül a hazánkban, illetve szűkebb környezetében, a Kárpátmedencében várható idójárási változásokkal foglalkoztunk. A globális melegedésnek számos jele van, illetve sok változást a melegedéssel lehet megmagyarázni. A mérések és megfigyelések szerint a magyarországi változások részben összhangban vannak a globális változásokkal, a hőmérséklet-változást illetôen mintha hazánkban nagyobb lenne az emelkedés. A globális százados emelkedési trend $0,8-0,9^{\circ} \mathrm{C}$, a homogenizált magyar adatokra viszont $1,0^{\circ} \mathrm{C}$-nál nagyobb trend illeszthető (SzENTimReY, T. et al. 2007). A globális felmelegedés, az éghajlatváltozás már eddig is olyan változásokat okozott, hogy a hatásaival való együttélésre, illetve a negatív hatások csökkentésére fel kell készülni. Ennek a remélhetôen összehangolt cselekvéssorozatnak fontos eleme annak ismerete, hogy mi várható a közeli, illetve a távoli jövőben. Ennek eszköze a klímamodell. Magyarország esetében további melegedésre kell számítani: az országos átlag az évszázad végére akár $4^{\circ} \mathrm{C}$-szal is meghaladhatja az 1961-1990-es referenciaszintet. A csapadék esetében - ami a mezógazdasági tevékenység fő támogatója vagy gátja lehet - viszont enyhe évi csökkenésre lehet számítani, ami egyúttal kevesebb, de intenzívebb csapadékkal jellemzett nappal fog együtt járni.

\section{Köszönetnyilvánítás}

A tanulmány a GINOP-2.3.4-15-2016-00005 számú projekt támogatásával készült.

DUNKEL ZOLTÁN

KE Növénytudományi Intézet, Kaposvár

dunkel.zoltan@ke.hu

Bozó LÁsZLó

Országos Meteorológiai Szolgálat

bozo.1@met.hu

GERESDI ISTVÁN

PTE TTK Földtani és Meteorológiai Tanszék, Pécs

geresdi@gamma.ttk.pte.hu

IRODALOM

BARTHOly J.-HASZPRA L.-Bozó,L. 2011: Klímaváltozás - 2011. Klímaszcenáriók a Kárpát-Medence Térségére. - MTA és ELTE Budapest. 279 p.

Em-Dat 2016: The OFDA/CRED International Disaster Database. - Université Catholique de, Louvain, Brussels, Belgium. www.emdat.be 
Geresdi I.-HorvÁth Á.-Bozó L. 2013: A víz szerepe a légköri folyamatokban. - Magyar Tudomány 174. 11. pp. 1293-1299. http://www.matud.iif.hu/2013/11/03.htm

Horváth Á.-NAGY A. 2012: 2011-2012 rendkívüli aszályai. - Természet Világa 143. 12. pp. 544-547. http://www.termeszetvilaga.hu/szamok/tv2012/tv1212/horvath.html

IPCC, 2007a: AR4 WG Report, http://www.ipcc.ch

IPCC, 2007b: ClimateChange 2007. The Scientific Basis, Contribution of Working Group I to the Fourth Assessment Report of the Intergovernmental Panel on Climate Change (IPCC)

IPCC, 2007c: Summary for Policymakers. In: Climate Change 2007: Mitigation. Contribution of Working Group III to the Fourth Assessment Report of the Intergovernmental Panel on ClimateChange. pp. 23.

IPCC, 2007d: Climate Change 2007: Impacts, Adaptation and Vulnerability. Contribution of Working Group II to the Fourth Assessment Report of the Intergovernmental Panel on Climate Change. Cambridge University Press, Cambridge, UK, pp. 976.

IPCC, 2011: Summary for Policymakers. In: Intergovernmental Panel on Climate Change Special Report on Managing the Risks of Extreme Events and Disasters to Advance Climate Change Adaptation. Cambridge University Press, Cambridge, UK and New York, NY, USA. pp. 30.

IPCC, 2013: AR5 WG Report, http://www.ipcc.ch

LAKATOS M.-Bihari Z.-SzEnTimRey T. 2016: Csapadékszélsőségek alakulása. - http://www.met.hu/eghajlat/ eghajlatvaltozas/megfigyelt_valtozasok/Magyarorszag/

PÉCZELY Gy. 1979: Éghajlattan. - Tankönyvkiadó, Budapest. 323 p.

PÉCZELY Gy. 1984: A Föld éghajlata. - Tankönyvkiadó, Budapest. 598 p.

SzÉPSZÓ, G. 2008: Regional change of extreme characteristics over Hungary based on different regional climate models of the PRUDENCE project. - Időjárás 112. pp. 265-284.

SzÉPSZÓ, G.-HORÁNYI, A. 2008: Transient simulation of the REMO regional climate model and its evaluation over Hungary. - Időjárás 112. pp. 203-231.

SZENTIMREY, T.-BIHARI, Z.-SZALAI, S. 2007: Comparison of geostatistical and meteorological interpolation methods (what is what?). - In: Dobesch, H.-Dumolard, P.-Dyras, I. (eds.): Spatial Interpolation for climate data - the use of GIS in Climatology and meteorology. [ISTE ltd., London, UK. pp. 45-56. 